\title{
BEDA MAKANAN, BEDA KEMAMPUAN PERHATIAN: STUDI EKSPERIMEN TENTANG PENGARUH GLYCEMIC INDEX CAUTION TERHADAP KEMAMPUAN DETEKSI SINYAL
}

\author{
Zulfikar Ali Farizi \\ Fathul Lubabin Nuqul \\ Fakultas Psikologi \\ Universitas Islam Negeri (UIN) Maulana Malik Ibrahim Malang \\ Jl. Gajayana 50 Malang Telp. 0341-558916
}

\begin{abstract}
In some nations have different eating patterns with other nations. There is consuming rice, sago, wheat and so on. Several studies have shown that meal consumption and types of food affect a person's cognition process. One of them is attentions. Based on Jenkins's study (1980) is known carbohydrate itself is divided by the speed of revamped into glucose in the body is divided into two, namely carbohydrates are quickly revamped into glucose or carbohydrate and high Glycemic index carbohydrates are slowly revampęd into glucose or carbohydrate low glycemic index. When a person consumes carbohydrate at a rate of speed of revamped into a different glucose certainly it will affect the brain's attention system. Attention is the ability to filter out some of the incoming stimulus of mental activity and focus on one the most important stimulus. Capability is very useful for human attention, because attention is the first gate of someone cognition processes. The research uses Crossover Experiment Design, and involves 20 graduate students as experiment subject. They are divided into 2 groups (high glycemic; rice, and low glycemic food; ubi). Subjects selected by controlling a few factor, such as, they has normal Intelligence, They has not severe disease and they are not overweight. To measure the attention ability used Attention Distraction. The results showed that the group fed high-glycemic carbohydrates (rice), have higher attention capacity compared with the provision of low glycemic carbohydrates (sweet potatoes). These results are consistent in the treatment of crossover.
\end{abstract}

Keywords: Attention, Meal, Carbohydrate, Glycemic Index

PSIKOISLAMIKA. Jurnal Psikologi Islam (JPI) copyright @ 2013 Laboratorium Penelitian, Kajian Psikologi Islam dan Penerbitan. Volume 10. Nomor 1, Tahun 2013

\section{PENDAHULUAN}

Manusia selalu membutuhkan energi untuk melakukan aktivitasnya sehari hari, baik itu aktivitas fisik yaitu aktivitas yang membutuhkan banyak tenaga seperti berlari, mengangkat barang berat dan juga kerja kasar maupun aktivitas kognitif seperti berfikir, menulis, menyetir, membaca dan lain sebagainya. Selain untuk beraktivitas energi juga digunakan untuk fungsi internal dalam tubuh. Energi yang dipakai manusia untuk beraktivitas tersebut berasal dari makanan yang dikonsumsi. Setiap hari tubuh memerlukan makanan yang memberi cukup energi yang sesuai dengan kebutuhan badan. Untuk menjaga kesehatan diperlukan adanya keseimbangan antara sumber energi yang masuk melalui makanan yang dikonsumsi oleh seorang individu dengan dengan energi yang dikeluarkan oleh individu tersebut, terutama untuk bekerja dan beraktivitas (Soekirmán, 2000)

Dalam ilmu gizi diketahui bahwa energi yang dibutuhkan oleh manusia dihasilkan oleh tiga zat gizi makro yaitu: karbohidrat, lemak dan protein. Menurut data FAO/WHO (1997) karbohidarat adalah sumber energi utama penduduk dunia. Sekitar 
40 - 80 persen energi penduduk dunia dipenuhi oleh karbohidrat. Angka tepatnya tergantung pada berbagai hal, antara lain geografi, budaya dan tingkat ekonomi. Di Asia dan Afrika presentase karbohidarat sebagai sumber utama energi lebih tinggi dibanding dengan di Eropa dan Amerika. Hal ini disebabkan karena karbohidrat lebih mudah didapat dan lebih ekonomis dari pada protein dan lemak. Di Indonesia sendiri 70 hingga 80 persen penduduk menggunakan beras (nasi) sebagai sebagai sumber karbohidarat utama atau lebih dikenal dengan istilah makanan pokok. Sisanya menggunakan terigu (dalam bentuk roti, dan mie). Jagung, umbi umbian (ubi jalar dan singkong), sagu (Soekirman, 2000). Sedangkan pada masyarakat yang mengalami kemajuan dalam tingkat ekonominya, menunjukkan pergeseran sumber energi dari karbohidrat ke arah protein dan lemak. Di negara-negara yang masyarakatnya mempunyai tingkat ekonomi yang tinggi seperti Amerika dan Eropa, jumlah energi di dalam makanan dapat mencapai 40 - 50 persen dari karbohidrat (Achmad Djaeni, 2010).

Karbohidrat yang dikonsumsi oleh manusia akan diubah menjadi glukosa atau gula darah yang akan menghasilkan energi yang diperlukan oleh tubuh, glukosa kemudian di angkut oleh darah dan kemudian digunakan sebagai bahan bakar untuk beraktifitas, sisanya akan disimpan dalam hati dan otot dalam bentuk glikogen dan bila masih lebih akan disimpan menjadi cadangan lemak. Energi dari glukosa tidak hanya dibutuhkan untuk kegiatan luar saja tetapi juga kegiatan internal, jaringan syaraf dan otak hanya bisa menggunakan glukosa sebagai bahan bakar untuk melakukan kegiatan termasuk di dalamnya berfikir dan aktifitas kognisi yang lain (Irawan, 2007). Selain itu otak merupakan organ tubuh yang mengkonsumsi energi dari paling banyak, yaitu 20 persen dari total asupan energi yang masuk dalam tubuh (Aswin, 2011). Hal itu sangat berkaitan dengan berbagai penelitian yang membuktikan bahwa makan pagi berpengaruh pada prestasi belajar anak. Anak yang tidak makan pagi, kurang dapat mengerjakan tugas di kelas yang memerlukan konsentrasi. Mereka umumnya mempunyai nilai hasil ujian yang lebih rendah, mempunyai daya ingat yang terbatas dan sering absen. Makan pagi berperan penting terutama untuk menyediakan energi dan gairah belajar dan bekerja di awal hari (Lloyd HM, Rogers PJ, 1994 dalam Soekirman : 57).

Menurut Sugiyanto (Astuti, 2008), konsentrasi adalah kemampuan memusatkan pemikiran dan kemampuan mental dalam penyortiran informasi yang tidak diperlukan dan memusatkan perhatian hanya pada informasi yang dibutuhkan. Matlin (1998) berpendapat bahwa konsentrasi adalah bagian dari perhatian (attention) karena perhatian memiliki pengertian yang lebih luas dari konsentrasi. Perhatian mempersiapkan individu untuk menerima berbagai pesan. Perhatian dapat digunakan untuk menjelaskan konsentrasi yang membutuhkan kemampuan untuk memisahkan stimulus yang tidak dikehendaki diantara sekian banyak stimulus yang tersedia. Matlin mendefinisikan konsentrasi sebagai aktivitas mental yang merupakan bagian dari perhatian. (Matlin, 1998 dalam Utami hal. 23).

Sarana utama dari segi gizi untuk memenuhi energi anak adalah dengan sarapan pagi. Sarapan pagi akan menyumbangkan gizi sekitar 25 persen (Khomsan dalam Adisty, 2004). Tanpa sarapan pagi, akan terjadi kekosongan lambung sehingga kadar glukosa akan menurun. Padahal glukosa darah merupakan sumber utama bagi otak. Dengan demikian, anak akan sulit menerima pelajaran dengan baik (Khomsan dalam Adisty, 2001). Tetapi perlu dicatat bahwa makan pagi yang dimaksud dalam penelitian tersebut adalah makan pagi yang memenuhi kebutuhan energi seperti makan nasi putih beserta lauk pauknya, bukan hanya minum air putih maupun minum teh dan makan kue kecil (Soekirman, Hardiansyah, jahari, 1999).

Karbohidrat sendiri terbagi atas dua macam kelompok berdasarkan susunan molekulnya, yaitu karbohidrat sederhana dan karbohidrat kompleks. Karbohidrat sederhana adalah karbohidrat yang tersusun dari 1 (monosakarida) hingga 2 (disakarida) molekul, jenis dari karbohidrat sederhana adalah gula pasir, sirop dan madu. Sedangkan karbohidrat kompleks adalah karbohidrat yang terbentuk oleh hampir 20.000 unit molekul monosakarida, jenis dari karbohidrat kompleks adalah sumber bahan pokok seperti padi, umbi-umbian, jagung dan gandum (Anwari, 2007).

Sebelum tahun 1981 para ilmuan berasumsi bahwa karbohidrat sederhana lebih cepat dicerna dan diserap dalam tubuh dan hal itu akan menyebabkan kenaikan glukosa dalam darah dengan cepat, sedangkan karbohidrat kompleks dicerna lebih lambat dan tidak menyebabkan kenaikan glukosa dengan cepat. Sehingga karbohidrat kompleks lebih dianjurkan untuk dikonsumsi dan karbohidrat sederhana dianjurkan untuk dihindari terutama untuk penderita diabetes (David Mendosa, 2010). Jenkins (1981) menemukan fenomena yang 
disebut Glykemik Indeks dalam pemecahan karbohidrat menjadi glukosa dalam tubuh. Dalam penelitian itu ditemukan bahwa karbohidrat yang memiliki nilai glykemik indek tinggi akan mudah dan cepat dipecah menjadi glukosa sehingga dapat menaikkan kadar gula darah sedangkan karbohidrat yang memiliki nilai glykemik indek rendah akan lebih lama dipecah menjadi glukosa sehingga tidak menyebabkan kenaikan gula darah. Nilai glykemik indek tersebut dimiliki oleh semua tipe karbohidrat, baik karbohidrat kompleks maupun karbohidrat sederhana, karbohidrat kompleks ada yang memiliki nilai glykemik indeks tinggi dan rendah begitu juga karbohidrat sederhana ada yang memiliki nilai glykemik indek tinggi dan rendah (Wikipedia, 2010).

Dari uraian diatas dapat dipastikan bahwa karbohidrat kompleks yang menjadi bahan pokok dan sumber energi manusia sehari-hari memiliki tingkat tingkat pemecahan glukosa dalam darah yang berbeda sesuai dengan nilai glykemik indek masing-masing dalam bahan makanan pokok tersebut. Jika suatu bahan makanan memiliki nilai glykemik indeks tinggi maka dapat dipastikan bahwa makanan tersebut akan cepat dipecah menjadi glukosa pada satu sampai dua jam setelah konsumsi, sehingga menyebabkan gula dalam darah menjadi tinggi, hal itu akan memancing produksi insulin yang akan menyebarkan glukosa darah keseluruh tubuh termasuk disimpan dalam hati dan otot dan kelebihannya akan disimpan sebagai cadangan lemak. Sedangkan bahan makanan yang memiliki glykemik indek rendah maka akan dipecah menjadi glukosa dengan lambat sehingga membuat kadar glukosa dalam darah stabil dan tidak memicu produksi insulin yang berlebih sehingga glukosa tidak segera disimpan dalam bentuk lemak dan bisa menjadi sumber energi yang konstan (Rai, 2006) terutama bagi anggota tubuh yang hanya mampu menggunakan glukosa sebagai sumber energi utama untuk melakukan tugasnya seperti otak (Khomsan, 2004 dalam Adisty). Konsumsi karbohidrat yang memiliki nilai glykemik indeks yang berbeda tentu akan berpengaruh pada kinerja otak dalam melakukan proses konsentrasi dan perhatian.

Proses perhatian dalam otak melibatkan dua sistem perhatian, yaitu sistem perhatian anterior yang terletak di dalam lobus frontalis yang menjadi aktif saat individu menjalankan tugas-tugas yang menuntut kesadaran seperti memfokuskan diri pada makna suatu kata-kata dan merencanakan atau memilih suatu tindakan dari sejumlah arah alternatif tindakan dan sistem perhatian posterior yang terletak dalam lobus parietalis dan juga seporsi talamus serta sejumlah wilayah otak tengah yang berkaitan dengan gerakan mata, sistem ini menjadi aktif saat individu melakukan tugas-tugas yang melibatkan perhatian visuo-spasia, dalam tugas ini individu harus melepas dan mengubah perhatian, contoh, penelusuran visual atau tugas-tugas kewaspadaan. Sistem-sistem perhatian anterior dan posterior tampaknya meningkatkan perhatian di berbagai tugas. Hal ini menunjukkan kalau kedua sistem tersebut terlibat dalam pengaturan pengaktifan wilayah-wilayah otak yang relevan bagi tugas-tugas tertentu yang tengah dihadapi dan menekan atau menghambat wilayah-wilayah otak yang tidak relevan bagi tugas-tugas yang tengah dihadapi (Poshner dan Dehaene, 1994 dalam Sternberg, 2008). Jika kedua sistem tersebut mendapat suplai glukosa sebagai bahan bakar utama otak secara konstan seperti pada karbohidrat dengan glikemik indeks rendah maka kedua sistem tersebut dapat bekerja maksimal sepanjang hari. Namun, jika glukosa sebagai bahan bakar utama hanya bisa disupali 2-3 jam saja dan setelah itu di simpan menjadi glikogen dan lemak seperti pada karbohidrat dengan glikemik indek tinggi maka kedua sistem tersebut akan cepat kehabisan suplai bahan bakar dan kurang bisa bekerja dengan maksimal sepanjang hari.

Selain itu semua penelitian mengenai efek dari gizi dan makanan terhadap kemampuan kognitif terutama konsentrasi kebanyakan menggunakan subyek anak-anak, masih jarang yang subyek penelitiannya adalah orang dewasa. Disisi lain kemampuan kognitif berupa perhatian atau konsentarsi yang dimiliki oleh anak-anak masih belum sempurna dan mudah terganggu oleh lingkungan (Utami, 2010).

Fokus permasalahan dalam penelitian ini adalah melihat apakah ada pengaruh konsumsi tipe karbohidrat terhadap kemampuan melakukan perhatian pada orang dewasa. Tujuan penelitian ini ingin mengetahui dan mendeskripsikan tenatang bagaimana efek konsumsi dari sumber energi yang mempunyai siafat pemecahan yang berbeda terhadap kemampuan kognitif seseorang teruatama perhatiannya.

\section{METODE PENELITIAN}

1. Partisipan

Partisipan pada penelitian kali ini berjumlah 20 orang, 10 orang berjenis kelamin laki-laki dan 10 orang berjenis kelamin perempuan, dengan kriteria: usia antara 20 - 25 tahun, tidak memiliki kelebihan berat badan (obesitas), sehat mental 
dan memiliki kapasitas intelegensi (IQ) rata-rata (90 - 109) atau lebih, tidak sedang menjalani diet khusus, dan tidak mengidap penyakit diabetes tipe 1 dan 2 sebanyak 20 Orang terdiri dari 10 orang laki-laki dan 10 orang perempuan. Dimana 20 orang tersebut akan dibagi menjadi dua secara imbang; 10 orang sebagai kelompok eksperimen 1 (terdiri dari 5 orang laki-laki dan 5 orang perempuan) dan 10 orang menjadi kelompok eksperimen 2 (terdiri dari 5 orang laki-laki dan 5 orang perempuan).

\section{Alat Pengumpul Data}

Metode pengumpulan data dalam penelitian ini menggunakan sebuah alat eksperimen untuk mengukur kemampuan perhatian bernama "Attention Distraction" yang di produksi oleh IDEAS (Industy of Electronic \& Software). Attention Distraction adalah alat yang menuntut pemusatan perhatian dan kecermatan yang sangat tinggi dengan jam khusus untuk mengukur waktu reaksi. Alat ini akan mengeluarkan sebuah stimulus berupa lampu yang menyala tetap dan lampu yang menyala kedap kedip. Setiap partisipan harus menghitung jumlah lampu yang menyala tetap yang tampil di layar dan meresponnya dengan memberikan jawaban dengan menyebutkan berapa jumlahnya dan lampu yang kedap-kedip merupakan distraktor. Setiap jawaban akan dicatat waktu reaksinya. Data disajikan dalam bentuk catatan waktu menggunakan satuan detik, semakin sedikit waktu reaksi berarti semakin baik kemampuan perhatian begitu pula sebaliknya.

\section{Rancangan penelitian}

Penelitian ini merupakan penelitian eksperimen yang bertujuan untuk mengetahui pengaruh perlakuan yang berupa konsumsi tipe karbohidrat terhadap kemampuan melakukan perhatian. Desain penelitian yang digunakan adalah rancangan Crossover dengan pembagian kelompok secara random, yakni sebgai berikut:

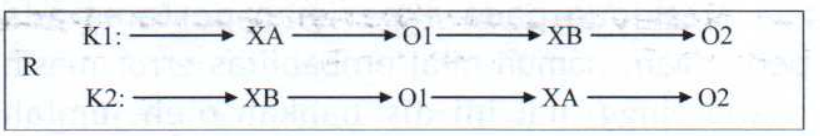

Gambar 1. Rancangan Penelitian Cross section experiment

Keterangan:

$\mathrm{R}$ : Random

XA : pemberian karbohidrat glikemik indeks tinggi

XB : pemberian karbohidrat glikemik indeks rendah

01 : pengukuran dengan alat Attention

\section{distraction}

02 : pengukuran dengan alat Attention distraction

\section{Prosedur eksperimen \\ a. Fase Persiapan.}

Pada masa persiapan dilakukan seleksi subyek penelitian (11 sampai 16 juli 2011 ). Seleksi subyek penelitian dilakukan oleh fasilitator dan ko-fasilitator dengan terjun langsung dilapangan, subyek yang dicari adalah 10 orang laki-laki dan 10 orang perempuan. Adapun kualifikasi subyek penelitian adalah: (a) usia antara 20-25 tahun; (b) memiliki kemampuan intelegensi atau IQ yang tergolong rata-rata yaitu antara 90 sampai 109 atau lebih; (c) memiliki berat badan yang ideal dan tidak masuk kategori obesitas; (d) sehat jasmani dan rohani serta tidak sedang dalam kondisi sakit; (e) tidak sedang mengidap diabetes tipe 1 dan 2; Setelah itu subyek penelitian dibagi menjadi dua kelompok secara acak melalui undian, setiap kelompok terdiri dari 5 orang laki-laki dan 5 orang perempuan. Pada eksperimen pertama Kelompok 1 diberi karbohidrat dengan glikemik indeks tinggi, sementara kelompok 2 diberi karbohidrat dengan glikemik indeks rendah. Pada eksperimen kedua kelompok 1 diberi karbohidrat dengan glikemik indeks rendah, sementara kelompok 2 diberi karbohidrat dengan glikemik indeks rendah.

\section{b. Fase Pelaksanaan}

Eksperimen dilakukan dengan memberikan perlakuan pemberian makanan karbohidrat dengan nilai glikemik indeks tinggi dan glikemik indeks rendah, dan kemudian di ukur pengaruhnya terhadap kemampuan melakukan perhatian. Program penelitian ini terdiri dari lima sesi dengan tiga kali pertemuan pada tiap kelompok dan setiap pertemuan berdurasi dua jam. Pemberian teratmen bertempat di labolaturium klasikal sedangkan untuk pengukuran dilakukan di labolaturium

Proses pemberian perlakuan Pada fase pertama kelompok A diberi Sarapan dengan karbohidrat glikemik indeks tinggi kemudian dilakukan pengukuran perhatian, sedangkan kelompok $\mathrm{B}$ diberikan dengan karbohidrat glikemik indeks rendah kemudian dilakukan pengukuran perhatian Pada fase ke dua kelompok B diberi Sarapan dengan karbohidrat glikemik indeks tinggi kemudian dilakukan pengukuran perhatian, sedangkan kelompok A diberikan dengan karbohidrat glikemik indeks rendah kemudian dilakukan pengukuran perhatian Pengukuran dilakukan 
dengan cara menghitung waktu reaksi menjawab benar sinyal yang diberikan dari alat.

\section{Metode Analisis Data}

Analisa data kuantitatif untuk menguji hipotesis dilakukan dengan menggunakan teksnik analisis uji T sampel independent dengan membandingkan rata-rata waktu reaksi antara kelompok eksperimen 1 dan kelompok eksperimen 2.

\section{HASIL PENELITIAN}

Hasil deskripsi penelitian tentang perbandingan waktu rata-rata antara kelompok yang diberi perlakuan karbohidrat dengan nilai glikemik indeks yang berbeda disajikan dalam bentuk gambar berikut ini:

Berdasarkan gambar 2 menunjukkan bahwa dalam eksperimen pertama kelompok yang diberi makanan glikemik rendah mempunyai perhatian yang lebih baik dibandingkan dengan kelompok yang diberi perlakukan dengan makanan karbohidrat glikelik tinggi.

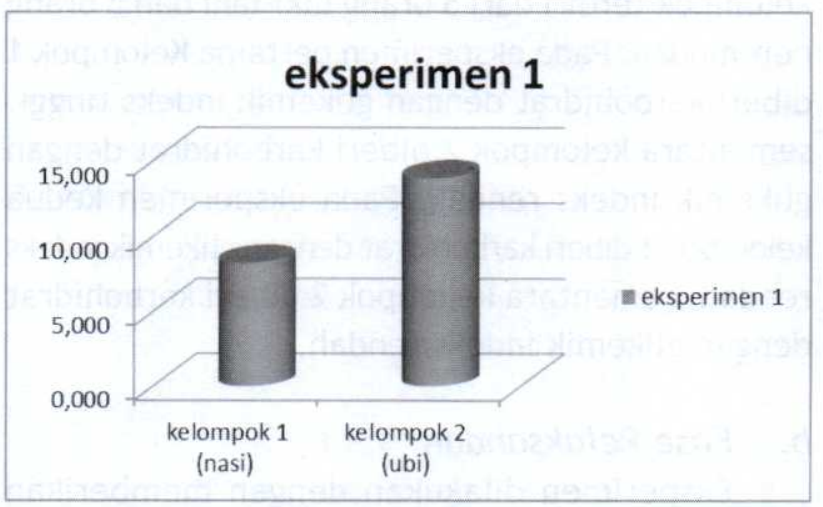

Gambar 2. Data reaksi waktu antar kelompok dalam eksperimen 1

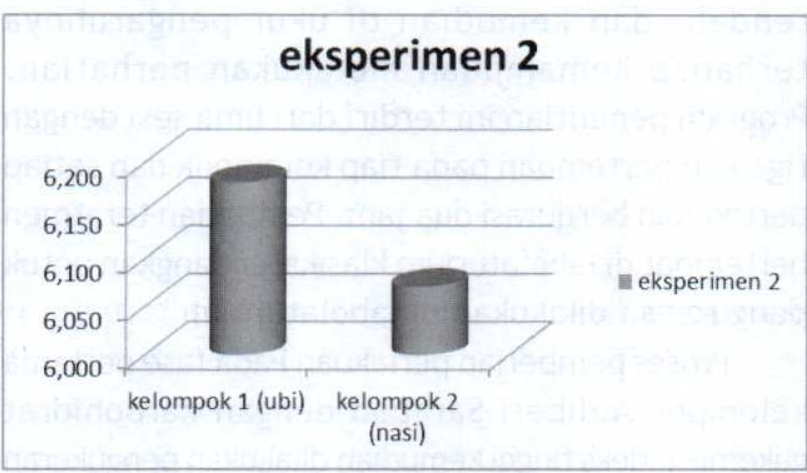

Gambar 3. Data reaksi waktu antar kelompok dalam eksperimen 2

Berdasarkan grafik deskriptif perbandingan rata-rata waktu reaksi antara kelompok 1 dan kelompok 2 diatas, diketahui bahwa rata-rata waktu reaksi kelompok yang diberi karbohidrat glikemik indeks rendah berada pada 6,179 detik, sedangkan rata-rata waktu reaksi kelompok yang diberi karbohidrat glikemik indeks tinggi berada pada 6,071 detik. Dengan demikian dapat diketahui berdasarkan perbandingan dari rata-rata waktu reaksi kelompok 2 lebih sedikit dibanding ratarata waktu reaksi kelompok 1 , itu berarti bahwa kelompok yang diberi perlakuan berupa karbohidrat glikemik indeks tinggi lebih cepat dari pada kelompok yang diberi perlakuan berupa karbohidrat glikemik indeks rendah.

Setelah dilakukan analysis independent sampel T-Test pada program SPSS 15.0 for windows, pada eksperimen pertama diperoleh nilai $\mathrm{P}=0,041$ ( $\mathrm{P}$ $<0,05)$. Maka dari hasil analisa kelompok yang diberi perlakuan berupa karbohidrat glikemik indeks tinggi dan kelompok yang diberi perlakuan berupa karbohidrat glikemik indeks rendah tersebut, terlihat bahwa secara statistik ada perbedaan yang signifikan dalam hal kemampuan melakukan perhatiannya. Dimana dengan pemberian Glikemic rendah lebih baik dalam mereaksi sinyal yang disajika. Pada eksperimen kedua diperoleh nilai $\mathrm{P}$ = 0,948 lebih besar dari pada 0,05 Maka dari hasil analisa kelompok yang diberi perlakuan karbohidrat glikemik indeks rendah dan kelompok yang diberi perlakuan berupa karbohidrat glikemik indeks rendah tersebut, terlihat bahwa secara statistik tidak ada perbedaan yang signifikan dalam hal kemampuan melakukan perhatian setelah diberi perlakuan.. Dibawah ini disajikan tabel hasil uji statistik dengan menggunakan uji T sampel independent.

Tabel 1 Ringkasan Hasil Analisa Independent Sampel T-Test

\begin{tabular}{|c|c|c|}
\hline \multirow{2}{*}{ Diskripsi Eksperimen } & \multicolumn{2}{|c|}{ Hasil } \\
\cline { 2 - 3 } & $\mathrm{T}$ & Sig. (1 tailed) \\
\hline Eksperimen pertama & 1.775 & 0.041 \\
\hline Eksperimen kedua & .066 & 0.948 \\
\hline
\end{tabular}

Meskipun pada ekperimen pertama ada perbedaan, namun nilai probabiitas error masih cukup tinggi hal ini disebabkan oleh jumlah subjek yang sedikit sehingga kurang tepat untuk analisis parametric, meskipun demikian Sadish et al (...) menyatakan bahwa dalam eksperimen nilai signifikansi boleh di abaikan, dan kesimpulan hasil bisa dilihat dari data deskripsi, walau alas an ini masih penuh perdebatan.

Dari hasil deskripsi waktu rata-rata antara kelompok 1 dan kelompok 2 diketahui bahwa pada eksperimen pertama waktu reaksi kelompok 1 
yang diberi perlakuan berupa karbohidrat glikemik indeks tinggi adalah 8,235 detik sedangkan waktu reaksi kelompok 2 yang diberi perlakuan berupa karbohidrat glikemik indeks rendah adalah 13,855 detik, artinya waktu reaksi kelompok 1 yang diberi perlakuan berupa karbohidrat glikemik indeks tinggi lebih baik dari pada waktu reaksi kelompok 2 yang diberi perlakuan berupa karbohidrat glikemik indeks rendah. Pada eksperimen kedua diketahui bahwa waktu reaksi kelompok 1 yang diberi perlakuan berupa karbohidrat glikemik indeks rendah adalah 6,179 detik sedangkan waktu reaksi kelompok 2 yang diberi perlakuan berupa karbohidrat glikemik indeks tinggi adalah 6,071 detik, artinya waktu reaksi kelompok 2 yang diberi perlakuan karbohidrat glikemik indeks tinggi lebih baik dari pada waktu reaksi kelompok 1 yang diberi perlakuan berupa karbohidrat glikemik indeks rendah . berdasarkan data dari eksperimen pertama dan kedua, dapat disimpulkan bahwa kelompok yang diberi perlakuan berupa karbohidrat glikemik indeks tinggi waktu reaksinya selalu lebih cepat dari pada kelompok yang diberi perlakuan berupa karbohidrat glikemik indeks rendah, artinya kemampuan subyek penelitian menjadi lebih baik dengan karbohidrat glikemik indeks tinggi dari pada dengan karbohidrat glikemik indeks rendah. Hasil tersebut mengindikasikan bahwa karbohidrat dengan nilai glikemik indeks tinggi lebih memberikan pengaruh positif pada kemampuan melakukan perhatian dari pada karbohidrat dengan nilai glikemik indeks rendah. Hal ini dikarenakan sistem perhatian di dalam otak yaitu sistem perhatian anterior yang terletak di lobus frontalis dan sistem perhatian posterior yang terletak di lobus parietalis, talamus dan otak tengah (Posner dalam Sternberg, 2008: 98) hanya dapat menggunakan glukosa yang ada secara konstan sebagai sebagai bahan bakarnya (Susanto, 2004: 24).

Karbohidrat dengan glikemik indeks tinggi (dalam penelitian ini adalah nasi dengan glikemik indeks : 90) merupakan jenis karbohidrat yang mudah dan cepat dipecah menjadi glukosa dalam tubuh setelah dikonsumsi, hal itu menyebabkan kenaikan kadar gula dalam dalam darah hingga 140 mg dalam kurun waktu 2 jam yang akan memancing tubuh untuk memproduksi hormon insulin, insulin akan mengantarkan seluruh glukosa dalam darah keseluruh sel-sel tubuh sebagai sumber energi untuk melakukan aktivitasnya, apabila masih ada kelebihan gula darah maka akan disimpan dalam otot dan hati sebagai glikogen, glikogen otot hanya bisa digunakan untuk kontraksi otot saja sedangkan glikogen hati dapat berfungsi untuk menjaga ketersediaan glukosa di dalam sel darah dan sistem syaraf pusat (Irawan, 2007). Maka dengan konsumsi karbohidrat glikemik indeks tinggi sistem syaraf pusat dan otak dapat bekerja dengan maksimal karena mendapat asupan glukosa yang menjadi bahan bakar utama secara penuh.

Karbohidrat dengan glikemik indeks rendah ( dalam penelitian ini menggunakan ubi dengan glikemik indeks : 44) merupakan jenis karbohidrat yang lambat dipecah menjadi glukosa setelah konsumsi, ketika karbohidrat dipecah secara perlahan maka hal itu tidak menyebabkan kenaikan gula dalam darah sehingga tidak memicu tubuh untuk memproduksi hormon insulin yang berperan sebagai agen pengantar glukosa keseluruh sel-sel dan sistem syaraf pusat, sehingga akan terjadi penurunan kadar gula darah dalam otak. Ketika otak tidak mendapat suplai glukosa yang tepat maka akan menyebabkan gangguan fungsi normal otak, termasuk sistem perhatian dalam otak.

Berdasarkan hasil uji T sampel independent diketahui bahwa nilai P pada ekseperimen pertama adalah 0,093 lebih besar dari pada 0,05. Sedangkan nilai $\mathrm{P}$ pada eksperimen kedua adalah 0,948 lebih besar dari pada 0,05. Dari kedua hasil tersebut dapat disimpulkan bahwa perbedaan kemampuan perhatian antara kelompok yang diberi perlakuan berupa karbohidrat glikemik indeks tinggi dan kelompok yang diberi perlakuan berupa karbohidrat glikemik indeks rendah tidak signifikan.

Pengaruh konsumsi tipe karbohidrat terhadap kemampuan perhatian kurang signifikan terhadap orang dewasa ini secara logika teoritis sangat mungkin kebenarannya, karena diketahui bahwa faktor usia ikut berpengaruh dalam kemampuan perhatian individu, kemampuan untuk melakukan perhatian ikut tumbuh dan berkembang sesuai usia individu. Kapasitas untuk melakukan perhatian pada orang dewasa lebih stabil dari pada anak-anak yang masih terbatas dan mudah terpecahkan ( Wickens dalam Astuti, 2008: 24). Hasil ini tentunya sangat berbeda dengan hasil penelitian terdahulu tentang pengaruh sarapan terhadap kemampuan perhatian yang dilakukan oleh Lloyd HM, Rogers PJ (Soekirman, 2000: 57), dimana dari penelitian tersebut ditemukan ada perbedaan yang signifikan antara konsentrasi pada siswa sekolah dasar yang sarapan dan siswa sekolah dasar yang tidak sarapan, sehingga perhatian pada anak-anak lebih mudah diganggu oleh rasa lapar dan kekurangan glukosa. 


\section{KESIMPULAN DAN SARAN}

1. Kesimpulan

Berdasarkan pemaparan dan rumusan masalah yang telah dijawab dalam penelitian ini dapat disimpukan bahwa tingkat kemampuan melakukan perhatian pada kelompok yang diberi karbohidrat glikemik indeks tinggi selalu lebih baik dari pada kelompok yang diberi karbohidrat glikemik indeks rendah. Hal ini menunjukkan bahwa pola makan dengan karbohidrat yang tinggi melemahkan kemampuan seseorang untuk merespon stimulus dengan baik.

\section{Saran-Saran}

Berdasarkan hasil penemuan yang telah diuraikan panjang lebar di atas, maka ada beberapa hal yang perlu direkomendasikan pada berbagai pihak.: Bagi masyarakat umum, penelitian ini dapat dijadikan pertimbangan dalam menentukan jenis

\section{DAFTAR PUSTAKA}

Alexa Hoyland, L. D. (2009). A System Review of the Effect of Breakfast On The Cognitive Performance Of Children And Adolescents. Nutrition Research Reviews. 22, 220-243

Allo, S. I. (2010). Asupan Zat Gizi Terhadap Prestasi Belajar Pada Remaja Putri Vegetarian Di Yayasan Advent Indonesia Makasar. Skripsi. Fakultas Kedokteran: Universitas Gadjah Mada Yogyakarta

Almatsier, S. (2010). Prinsip Dasar Ilmu Gizi. Jakarta: PT. Gramedia Pustaka Utama.

Amanda Ledika, M., Irawan Nugraha, G., \& Sedjati Rasjad, A. (2009). Indeks Glikemik Berbagai Makanan Sarapan Indonesia. Bandung: www. Google.com.

Aminuddin. (2009, Maret 26). Diet Diabetes: Memahami Dan Menggunakan Indeks Glikemik Makanan Dan Indeks Glikemik Load. Aminuddin Blog, pp. 1-2.

Arikunto, S. (2005). Manajemen Penelitian. Jakarta: Rineka Cipta.

Astuti, E. P. (2008). Hubungan Kontribusi School Feeding Terhadap Konsentrasi Belajar Pada karbohidrat yang dikonsumsi untuk meningkatkan kemampuan konsentrasi terutama bagi orang-orang yang kesehariannya membutuhkan konsentrasi dalam melakukan aktivitas hariannya.

Bagi lembaga pemerintahan dan lembaga pendidikan; hasil penelitian ini bisa digunakan sebagai bahan untuk melakukan penyuluhan tentang pentingnya mengkonsumsi karbohidrat dengan kualitas yang baik demi meningkatkan kemampuan konsentrasi.

Bagi peneliti selanjutnya, perlu dilakukan penelitian lebih lanjut mengenai efek konsumsi karbohidrat berdasarkan nilai glikemik indeksnya terhadap kemampuan kognitif yang lain selain perhatian. Selain itu juga perlu diteliti lebih lanjut efek konsumsi tipe karbohidrat terhadap individu yang sudah tua. Juga perlu memerhatikan faktorfaktor psikologis yang berpengaruh pada kemampuan perhatian.

Siswa Sekolah Dasar Islam Terpadu Luqman Al Hakim Yogyakarta. Skripsi. Fakultas Kedokteran: Universitas Gadjah Mada Yogyakarta

Aswin, S. (2011). Peranan Otak Terhadap Perilaku. National Conference On Biopsychology (p. 5). Yogyakarta: Fakultas Psikologi UGM.

Budianto, A. K. (2009). Dasar-Dasar Ilmu Gizi. Malang: UMM Pres.

Desmita. (2008). Psikologi perkembangan. Bandung: PT Remaja Rosdakarya .

Fadillah, A. S. (2009). 5 Pilihan Diet Yang Cocok Untuk Anda. Reps, 09-10.

Greenwood, C. E. (2003). Dietary Carbohidrate, Glucose Regulation, and Cognitive Performance in Erderly Persons. Nutrition Review, 68-74.

Home Of Glycemic Index. (2011, April 11). About Glycemic Index. Gycemic Index Testing \& Research, pp. 1-4.

Irianto, D. P. (2007). Panduan Gizi Lengkap Keluarga Dan Olahragawan. Yogyakarta: Penerbit ANDI.

Kalat, J. W. (2010). Biopsikologi Jilid 2. Jakarta: Salemba humanika. 
Kerlinger, F. N. (2006). Asas-Asas Penelitian Behavioral. Yogyakarta: Gadjah Mada University Press.

Krisna, A. D. (2008, April 26). Diet Dan Nutrisi Penting. Indeks Glikemik, p. 2.

Latipun. (2010). Psikologi Eksperimen. Malang: UMM Press.

Liche Seniati, A. Y. (2009). Psikologi Eksperimen. Jakarta: Indeks.

Mendosa, D. (2010). Indeks Glikemik. Living With Diabetes, 5-6.

Muchtadi, D. (2009). Pengantar Ilmu Gizi. Bandung: Alfabeta.

Pinel, J. P. (2009). Biopsikologi. Yogyakarta: Pustaka Pelajar.

Rai, A. (2006). Gaya Hidup Sehat Fitnes Dan Binaraga. Jakarta: Tabloid Bola.

Santoso, G. H. (2008, Juni 3). Index Glikemik. Index Glikemik (Yang Mau Diet Harus Ngerti), pp. 1-2.

Sediaoetama, A. D. (2010). Ilmu Gizi Untuk Mahasiswa Dan Profesi. Jakarta: Dian Rakyat.

Shadish, Cook, \& Champbell. (2002). Experimental And Quasi-Experimental Designs For Generalized Causal Inference. New York: Houghton Mifflin Company.

Soekirman. (2000). Ilmu Gizi \& Aplikasinya Untuk Keluarga \& Masyarakat. Direktorat Jendral Pendidikan Tinggi. Dep. Pendidikan Nasional.
Solso, R. L., Otto, H. M., \& Maclin, M. K. (2008). Psikologi Kognitif. Jakarta: Penerbit Erlangga.

Sternberg, R. J. (2008). Psikologi Kognitif. Yogyakarta: Pustaka Pelajar.

Sugiono. (2008). Metode Penelitian Kuantitatif Kualilitatif dan R\&D. Bandung: Alfabeta.

Suharnan. (2005). Psikologi Kognitif. Surabaya: Srikandi.

Susanto, T. D. (2004). Dasar-Dasar Ilmu Pangan Dan Gizi. Yogyakarta: Akademika Yogya.

The Medical News. (2010, Desember 15). Indeks Glikemik. Apakah Indeks Glikemik?, pp. 1-9.

Utami, A. N. (2010). Perbedaan Kemampuan Kognitif Berdasarkan Kebiasaan Sarapan, Status Anemia, Dan Status Gizi Pada Anak Sekolah Dasar. Yogyakarta: Skripsi. Fakultas Kedokteran: Universitas Gadjah Mada Yogyakarta

Wayler, T. F. (1966). Applied Nutrition. New York: The Mac Millian Company.

Wikipedia. (2010, Desember 5). Indeks Glikemik. Faktor-faktor Yang Mempengaruhi Indeks Glikemik Pangan, pp. 1-3.

Wikipedia. (2010, Desember 21). Indeks Glikemik. Indeks Glikemik Makanan, pp. 1-6.

Wikipedia. (2010, Desember 23). Karbohidrat. Karbohidrat, pp. 1-5. 